\title{
Application of mathematical models for the prediction of adsorption isotherms in solid mixture for mango powder refreshment
}

\author{
Aplicação de modelos matemáticos na predição de isotermas \\ de adsorção de preparado sólido para refresco em pó de manga
}

\author{
Edmar CLEMENTE ${ }^{1 \star}$, Marcos Rodrigues Amorim $\mathrm{AFONSO}^{2}$, Ana Paula SOUZA², \\ José Maria CORREIA ${ }^{2}$, Raquel Gomes PIRES ${ }^{2}$, Geraldo Arraes MAIA ${ }^{3}$
}

\begin{abstract}
Solid mixtures for refreshment are already totally integrated to the Brazilian consumers' daily routine, because of their quick preparation method, yield and reasonable price - quite lower if compared to 'ready-to-drink' products or products for prompt consumption, what makes them economically more accessible to low-income populations. Within such a context, the aim of this work was to evaluate the physicochemical and mineral composition, as well as the hygroscopic behavior of four different brands of solid mixture for mango refreshment. The BET, GAB, Oswim and Henderson mathematical models were built through the adjustment of experimental data to the isotherms of adsorption. Results from the physiochemical evaluation showed that the solid mixtures for refreshments are considerable sources of ascorbic acid and reductor sugar; and regarding mineral compounds, they are significant sources of calcium, sodium and potassium. It was also verified that the solid mixtures for refreshments of the four studied brands are considered highly hygroscopic.

Keywords: adsorption; isotherms; mathematical models; nutritious powders; refreshment; mango.
\end{abstract}

\section{Resumo}

Os preparados sólidos para refresco já estão perfeitamente integrados ao dia a dia do consumidor brasileiro, em função da sua facilidade de preparo, rendimento e do preço de mercado, bastante inferior, se comparado às bebidas prontas para o consumo, o que o torna mais acessível economicamente, principalmente para as populações de baixa renda. Dentro deste contexto, neste trabalho, objetivou-se avaliar à composição físico-química, mineral e o comportamento higroscópico de quatro diferentes marcas de preparado sólido para refresco sabor manga. As isotermas de adsorção foram construídas através do ajuste de dados experimentais aos modelos matemáticos de BET, GAB, Oswim e Henderson. Os resultados físico-químicos da avaliação mostram que os preparados sólidos para refrescos são fontes consideráveis de ácido ascórbico e açúcar redutor e no que se refere à composição mineral são fontes importantes de cálcio, sódio e potássio. Foi também observado que os preparados sólidos das quatro marcas estudadas são produtos muito higroscópicos.

Palavras-chave: adsorção; isotermas; modelos matemáticos; pós alimentícios; refrescos; manga.

\section{Introduction}

In Brazil, powder drinks were relegated to the stigma of second line and 'popular' products, in spite of having significant participation in the drink-consumption market. Since the end of the 1990s, the formulation of powder mixtures for refreshments has been gradually modified to become more attractive to the consumer, with the addition of pulp and/or dehydrated fruit juice and soluble fibers to the usual composition (CALEGUER, 2005).

Solid mixtures for refreshment, popularly known as refreshment powder are totally integrated to the Brazilian consumer's daily life. Refreshment preparation is easy, its yield is voluminous, and market price is quite low compared to drinks known as 'ready-made for consumption drinks', what makes refreshments economically more accessible, mainly to the low-income populations (INSTITUTO..., 2007).
Powdered mixtures for refreshment appeared in the 1960s and they were sold in small bags containing $6 \mathrm{~g}$ each; and at that time, the product was not sweetened. Towards the end of the 70s, refreshments began to be pre-sweetened in order to make the preparation easier. In the beginning of the 80 s, came the mixed formulation of sugar and artificial sweetener. In the late 90s, the strong artificial flavoring of powder refreshment began to lose its market share to soft drinks. In 1999, powder refreshment began to recover its market share due to the appeal brought by 'pulp addition' and/or because of the fruit juice picture printed on packages of the main manufacturers of the refreshment segment; thus, changing the product concept in the eyes of consumers. Recently, refreshments got a better appearance regarding the product and new packages, and started to be offered in refined selling points, becoming a commodity

\section{Received 1/6/2009}

Accepted 18/5/2010 (004227)

${ }^{1}$ Laboratório de Bioquímica de Alimentos, Departamento de Química, CCE, Universidade Estadual de Maringá - UEM, CEP 87020-900, Maringá, PR, Brasil,

e-mail:eclemente@uem.br

${ }^{2}$ Departamento de Tecnologia de Alimentos - DETAL, Universidade Federal do Ceará - UFC, CEP 60455760, Fortaleza, CE, Brasil

${ }^{*}$ Corresponding author 
and replacing natural juices (FUJII, 1999; CALEGUER, 2005; CALEGUER; BENASSI, 2007).

Although powder refreshments are well known products and highly appreciated by the population in general, just a few scientific papers have been published focusing powder refreshments and assessing their chemical, physiochemical and mineral composition, and hygroscopic behavior after elaboration. With the growing popularization and consumption of these products, it is important to know the contents of vitamin C, sugars, minerals and other components, as well as the stability of such components - once the solid mixtures for refreshments are usually used in substitution to fruit juices 'in natura' (SILVA et al., 2005).

Dehydrated powdered products are largely used in several instant food formulations, as they are easy to be used in an addition and mixture operation in industrial scale. Such products are characterized for their high contents of soluble solids, with an appreciable portion of these contents in amorphous state (glassy/vitreous), what makes them highly hygroscopic and subject to undesirable physical changes (SLADE; LEVINE, 1995; GENIN; RENÉ, 1995; PEREIRA, 2000; CARLOS; RESENDE; CAL-VIDAL, 2005; FELIPE et al., 2006).

Hygroscopicity is the property of a food product to absorb moisture from the atmosphere. Depending on the type of food product, such hygroscopicity may be beneficial, as it is the case of bread and cakes; or it may be harmful, as in candies, solid mixtures for refreshments, sugars, among others (MARTINS, 2001). It is very important to know the hygroscopic behavior of solid mixtures for refreshment and build their adsorption isotherms to predict suitable conservation conditions, to develop appropriate packaging methods and to know the equilibrium moisture content (COSTA, 1991). Aiming to predict the behavior of adsorption isotherms, several authors proposed isotherm fitting models. These models are useful in order to know the physical and physiochemical characteristics of food products (PENA; RIBEIRO; GRANDI, 2000; FERREIRA; PENA, 2003; CORRÊA et al., 2006; LUZ et al., 2006; ANSELMO et al., 2006; RESENDE et al., 2006). Based on the points emphasized, the aim of the present work was to evaluate the physiochemical and mineral characterization, as well as the hygroscopic behavior, through the establishment of adsorption isotherms of the solid mixture for preparation of mango-flavored refreshment of four different brands.

\section{Materials and methods}

Sachets of solid mixture for mango refreshment, containing $1 \%$ of dehydrated fruit pulp, were used for carrying out the experiments. Four different brands sold in the region of Fortaleza-CE were chosen; they will be named A, B, C and $\mathrm{D}$, in this work. According to the product labels, all four brands presented in their formulation, substances such as: granulated sugar, acidulate, dehydrated pulp (1\%), stabilizer, anti-moisture/humectants, flavoring, inorganic coloring, artificial sweeteners, antioxidants, artificial coloring and phenylcetonurics.

The samples of the different brands were sent to the Fruit and Vegetable Laboratory of the Food Technology Department at the
Federal University of Ceara. In the characterization of samples, the following physiochemical analyses were carried out: soluble solids ( $\left.{ }^{\circ} \mathrm{Brix}\right)$ with ATAGO N1field refratometer; total titratable acidity; moisture contents; $\mathrm{pH}$, ascorbic acid; reductor sugars; total sugars and ash. The physiochemical analyses were performed according to the methodology described by Brasil (2005). The cations calcium, sodium, potassium, magnesium, iron, zinc, copper and manganese, were analyzed for mineral characterization, according to AOAC (ASSOCIATION..., 1995). All physiochemical and mineral analyses were performed in triplicate.

To determine the adsorption isotherms, samples were weighed, in triplication, with $0.50 \mathrm{~g}$ each, and were placed in previously tared aluminum crucibles. After that, the crucibles were put on a support placed inside isolated cells, which contained saturated saline solutions, in agreement with GREESPAN (1977), shown in Table 1. The temperature used for the construction of isotherms was $21^{\circ} \mathrm{C}$.

The crucibles containing the samples were weighed every 48 hours until they reached the equilibrium moisture content that is a constant weight; no mass variation was detected by weighing the samples in a METTLER H80 analytical scale. The samples were, then, taken to the oven in order to determine their moisture contents. Equilibrium moisture content $\left(X_{e q}\right)$ was calculated by the difference between the mass presented by the sample in the equilibrium and its dry mass (Equation 1):

$X_{e q}=\frac{m_{o}-m_{s}}{m_{s}}$

where:

$X_{e q}=$ equilibrium moisture content ( $\mathrm{g} \cdot \mathrm{g}^{-1}$ of dry matter);

$m_{o}=$ sample mass in balance $(\mathrm{g})$;

$m_{s}=$ mass of dry sample $(\mathrm{g})$.

For the mathematical fitting of experimental data of adsorption isotherms, the mathematical models used were those by Brunauer, Emmet and Teller (BET); Guggenheim-Anderson-De Boer (GAB); Henderson; Oswin, represented, respectively, by Equations 2, 3, 4 and 5.

$X_{e q}=\frac{X_{m} \cdot C \cdot a_{w}}{\left(1-a_{w}\right)} \cdot\left[\frac{1-(n+1) \cdot\left(a_{w}\right)^{n}+n \cdot\left(a_{w}\right)^{n+1}}{1-(1-C) \cdot a_{w}-C \cdot\left(a_{w}\right)^{n+1}}\right]$

$X_{e q}=\frac{X_{m} \cdot C \cdot K \cdot a_{w}}{\left(1-K \cdot a_{w}\right) \cdot\left(1-K \cdot a_{w}+C \cdot K \cdot a_{w}\right)}$

Table 1. Water Activity at $21^{\circ} \mathrm{C}$ of saturated saline solutions used by Greespan (1977).

\begin{tabular}{cc}
\hline Saturated solutions & Water activities \\
\hline $\mathrm{K}_{2} \mathrm{CO}_{3}$ & 0.48 \\
$\mathrm{Mg}\left(\mathrm{NO}_{3}\right)_{2}$ & 0.55 \\
$\mathrm{NaBr}$ & 0.57 \\
$\mathrm{NaCl}$ & 0.76 \\
$\mathrm{SnCl}_{2}$ & 0.84 \\
$\mathrm{BaCl}_{2}$ & 0.92 \\
\hline
\end{tabular}


$X_{e q}=\left[\frac{-\ln \left(1-a_{w}\right)}{b}\right]^{\frac{1}{a}}$

$$
X_{e q}=a \cdot\left[\frac{a_{w}}{1-a_{w}}\right]^{b}
$$

where:

$$
a_{w}=\text { water activity; }
$$

$X_{m}=$ moisture contents in molecular monolayer $\left(\mathrm{g} \cdot \mathrm{g}^{-1}\right.$ of dry matter);

$X_{e q}=$ equilibrium moisture content expressed in $\left(\mathrm{g} \cdot \mathrm{g}^{-1}\right.$ of dry matter);

$n=$ number of molecular layer;

$C=$ BET constant, related to the heat of adsorption of molecular layer;

$a, b$ and $K=$ fitting parameters.

The values of error (E), shown in Table 4, were calculated according to Equation 6 (KUROZAWA et al., 2005).

$E=\frac{100}{n} \sum_{i=1}^{n} \frac{\left|\left(M_{i}-M p_{i}\right)\right|}{M_{i}}$

$E=$ relative medium error;

$M_{i}=$ values obtained experimentally;

$M_{p i}=$ values predicted by the model;

$n=$ number of experimental data.

\section{Results and discussion}

\subsection{Physiochemical characterization of solid mixture prepared for mango powder refreshment}

Table 2 shows the results of the following physiochemical parameters: $\mathrm{pH}$, total titratable acidity, soluble solids ( ${ }^{\circ} \mathrm{Brix}$ ), non-reductor sugars, total sugars, ascorbic acid, ash and moisture of solid mixtures for mango flavored refreshment of four different brands.
The $\mathrm{pH}$ of the brands investigated varied from 3.18 to 3.80 , showing statistical difference between them at $5 \%$ probability. Brand $\mathrm{B}$ presented a $\mathrm{pH}$ of 3.31 , a value that is within the range established by the Identity and Quality Standards for fruit pulps (BRASIL, 1999), and it is equal to the percentage found in frozen mango pulp by Bueno et al. (2002), when studying pulp quality. Possibly, this $\mathrm{pH}$ value, which is close to the ones found in the literature, is correlated to the contents of fruit (mango) pulp added to the formulation of solid mixtures for refreshment. Gomes, Figueirêdo and Queiroz (2004) observed the stability of the pulp of powdered acerola (Barbados cherry) and found $\mathrm{pH}$ values almost unaffected, ranging between 3.7 and 3.8.

Among the brands investigated, ascorbic acid contents varied from $71.82 \mathrm{mg} .100 \mathrm{~g}^{-1}$ to $282.13 \mathrm{mg} .100 \mathrm{~g}^{-1}$. Such a high variation in contents of ascorbic acid may be associated to the different processes of refreshment production used by the different industries, and also because of the probable enrichment of solid mixtures with this compound by the manufacturers. Brands A, B and D presented statistical difference between them at $5 \%$ probability. These values are significantly above the values found by Grizotto, Aguine and Menezes (2005) $2 \mathrm{mg} .100 \mathrm{~g}^{-1}$ in mango pulp in natura'. Bastos et al. (2005) found $28.75 \mathrm{mg} .100 \mathrm{~g}^{-1}$ of ascorbic acid in dehydrated mango of the Tommy Atkins variety. This value is lower than those found in the different brands of mango solid mixtures investigated in this work.

The soluble solids determined varied from 91 to $105^{\circ}$ Brix, not presenting statistical difference between them at the level of $5 \%$ probability. The concentrations of all brands analyzed are above the $11.40^{\circ} \mathrm{Brix}$, in average, obtained by Brunini, Durigan and Oliveira (2002), when evaluating the alterations of Tommy Atkins mango frozen pulp. The high values of soluble solids found in the solid mixtures of mango are justified because the product is in powder form and, therefore, more concentrated; and also due to sucrose addition, in different levels, by the product manufacturers. Oliveira, Figueiredo and Queroz (2006) found contents of soluble solids in pulps of integral surinam cherry and powder form of $7^{\circ} \mathrm{Brix}$ and of $14.60^{\circ} \mathrm{Brix}$, respectively; whereas, Pereira, Queiroz and Figueiredo (2006) obtained $1.54^{\circ} \mathrm{Brix}$ to $1.80^{\circ} \mathrm{Brix}$ in powder tomato.

Regarding non-reductor sugars, it may be observed that the values found are quite close to each other, within $79.17 \%$ and $84.13 \%$. Only brand B showed significant difference among all the four brands studied. The presence of reductor sugars was

\begin{tabular}{|c|c|c|c|c|}
\hline \multirow[t]{2}{*}{ Parameters } & \multicolumn{4}{|c|}{ Powder refreshment brands } \\
\hline & $\mathrm{A}$ & B & $\mathrm{C}$ & $\mathrm{D}$ \\
\hline $\mathrm{pH}$ & $3.18 \pm 0.42^{c}$ & $3.31 \pm 0.42^{b c}$ & $3.80 \pm 0.00^{\mathrm{a}}$ & $3.50 \pm 0.10^{b}$ \\
\hline Ascorbic acid (mg.100 g $\mathrm{g}^{-1}$ ) & $177.64 \pm 28.73^{b}$ & $71.82 \pm 25.39^{c}$ & $217.80 \pm 18.75^{\mathrm{ab}}$ & $282.13 \pm 0.00^{\mathrm{a}}$ \\
\hline Soluble solids at $20^{\circ} \mathrm{C}$ ( ${ }^{\circ}$ Brix) & $97.0 \pm 7.07^{\mathrm{a}}$ & $91.0 \pm 1.41^{\mathrm{a}}$ & $91.20 \pm 0.00^{\mathrm{a}}$ & $91,00 \pm 1,41^{\mathrm{a}}$ \\
\hline Non-reductor sugar (\%) & $79.45 \pm 0.68^{\mathrm{b}}$ & $84.13 \pm 1.07^{\mathrm{a}}$ & $79.17 \pm 1.07^{b}$ & $80.62 \pm 0.14^{\mathrm{b}}$ \\
\hline Total sugar $(\%)$ & $79.45 \pm 0.68^{\mathrm{b}}$ & $84.13 \pm 1.07^{\mathrm{a}}$ & $79.17 \pm 1.07^{\mathrm{b}}$ & $80.62 \pm 0.14^{\mathrm{b}}$ \\
\hline Total titratable acidity (\%) & $0.84 \pm 0.28^{\mathrm{a}}$ & $0.47 \pm 0.18^{b}$ & $0.39 \pm 0.21^{\mathrm{b}}$ & $0.42 \pm 0.00^{\mathrm{b}}$ \\
\hline Moisture (\%) & $0.66 \pm 0.28^{\mathrm{a}}$ & $0.59 \pm 0.14^{\mathrm{a}}$ & $0.28 \pm 0.00^{\mathrm{b}}$ & $0.67 \pm 0.35^{\mathrm{a}}$ \\
\hline Ashes (\%) & $0.36 \pm 0.00^{\mathrm{a}}$ & $0.17 \pm 0.14^{\mathrm{a}}$ & $0.25 \pm 0.21^{\mathrm{b}}$ & $0.16 \pm 0.14^{\mathrm{c}}$ \\
\hline
\end{tabular}

Table 2. Mean values of physicochemical parameters, in four different brands of solid mixture for preparation of mango refreshment.

Mean values in the same line, with same small letters, do not differ significantly at $5 \%$ probability, according to Tukey's test. 
not detected; therefore, the total sugars of the solid mixtures are limited to non-reductor sugars presence.

The total titratable acidity varied from 0.39 to $0.84 \%$, thus showing that brand A differs statistically from the others. A relation between acidity and $\mathrm{pH}$ can be observed. It was observed that sample $\mathrm{C}$ presented higher $\mathrm{pH}$ and showed the lowest acidity contents; whereas sample A, which presented lower $\mathrm{pH}$, showed the highest acidity. Oliveira, Figueiredo and Queiroz (2006) found values of acidity for integral Suriname cherry, and also in powder form formulated with $15 \%$ of maltodextrin $+30 \%$ of distilled water of $2.23 \%$ and $1.52 \%$, respectively; and Pereira, Queiroz and Figueiredo (2006) found values ranging from $6.68 \%$ to $6.84 \%$ in powdered tomato. In the studied samples, moisture varied from $0.28 \%$ to $0.67 \%$, and brand $\mathrm{C}$ was the only one that presented statistical difference in comparison to the other samples.

Ash contents varied from $0.16 \%$ to $0.36 \%$ and brands $\mathrm{A}$ and $\mathrm{B}$ presented significant differences at the level of 5\%, compared to brands $\mathrm{C}$ and $\mathrm{D}$. It was observed that brand A presented the highest ash contents, whereas brand D presented the lowest one.

\subsection{Mineral characterization of solid mixtures for preparing mango powder refreshment}

Table 3 shows values obtained in this study regarding mineral composition of solid mixtures for mango refreshments of four different brands. Calcium contents varied from 1442.08 to $6306.92 \mathrm{mg} .100 \mathrm{~g}^{-1}$. Brand A differs statistically at the level of $5 \%$ probability from the other brands. It was also observed that brand A had the highest calcium contents, approximately five times higher than the calcium contents of brand C. However, such a high value was found in products in powder form, and the solid mixtures for refreshment are diluted in water before being consumed - according to the manufacturer's directions, which reduces the calcium contents in the product ready for consumption. Thus, if the Recommended Dietary Allowances (RDA) of this mineral is taken into consideration, which, according to Brasil (2004) is in average $1000 \mathrm{mg}$ /day for adults, the ingestion of 3 to 7 glasses of $200 \mathrm{~mL}$ of refreshment would be necessary.

The sodium contents varied from 2317.76 to $7118.22 \mathrm{mg} 100 \mathrm{~g}^{-1}$ in the investigated brands, and no differences were observed between brands $\mathrm{A}$ and $\mathrm{C}$ and brand $\mathrm{D}$, but they showed differences between themselves at the level of 5\% probability, and also in relation to brand $\mathrm{B}$. The contents of sodium found in brand $\mathrm{C}$ were three times higher than those found in brand B. In order to supply the need of sodium in the organism through the ingestion of refreshment made with mango solid mixture, it would be necessary to drink from 3 to 11 glasses of $200 \mathrm{~mL}$ (BRASIL, 2004).

Potassium contents varied from 289.72 to $1389.33 \mathrm{mg} .100 \mathrm{~g}^{-1}$, which permits to observe that brands $\mathrm{C}$ and $\mathrm{D}$ did not differ between them at the level of $5 \%$ probability; however, they differed in brands A and B. The potassium contents found in a $200 \mathrm{~mL}$ glass of refreshment was equivalent to 1.30 to $4.17 \%$ of the RDA, and the highest value was observed in brand $\mathrm{A}$, whereas the lowest was found in brand $\mathrm{B}$. Concerning magnesium, its contents varied from 80.38 to $573.41 \mathrm{mg} .100 \mathrm{~g} \mathrm{~g}^{-1}$, and it was observed that brand $\mathrm{D}$ was statistically different from the other analyzed brands.

Iron contents in the brands under investigation did not show statistical difference at the level of $5 \%$ probability; however, the refreshment made with the brand D solid mixture, which showed the highest iron content, was equivalent to $128.15 \%$ of RDA for an adult person, thus, indicating that the solid mixtures are good sources of iron. Regarding zinc, it was observed that the contents varied from 6.79 to $33.04 \mathrm{mg} .100^{-1}$, and that only brand D presented statistical difference at the level of $5 \%$ significance. It was also observed that the zinc contents found in brand D was higher than the sum of all concentrations in the three brands (A, B and $\mathrm{C}$ ) together.

Copper and manganese contents shown in Table 3 varied from 1.59 to $7.27 \mathrm{mg} .100 \mathrm{~g}^{-1}$ and from 2.29 to $5.50 \mathrm{mg} .100 \mathrm{~g}^{-1}$, respectively, thus not showing statistical differences between the studied the brands. It is worth emphasizing that copper in brand B showed the lowest contents in comparison to the other brands, whereas brand D showed the highest values. Regarding manganese, it was observed that only brand $\mathrm{C}$ showed higher contents of this mineral.

Due to the low water content in the solid mixture for mango refreshment, all mineral contents of the samples studied in Table 3 are above the figures found by Morgano, Queiroz and Ferreira (1999) regarding mineral contents in fruit juices. In that study, the author obtained average medium values for calcium, magnesium, iron, manganese, sodium, potassium, zinc and copper of $5.63 \mathrm{mg} .100 \mathrm{~g}^{-1} ; 7.25 \mathrm{mg} .100 \mathrm{~g}^{-1} ; 0.12 \mathrm{mg} .100 \mathrm{~g}^{-1}$; $0.34 \mathrm{mg} .100 \mathrm{~g}^{-1} ; 15.45 \mathrm{mg} .100 \mathrm{~g}^{-1} ; 114.35 \mathrm{mg} .100 \mathrm{~g}^{-1}$; $0.057 \mathrm{mg} .100 \mathrm{~g}^{-1}$ and $0.07 \mathrm{mg} .100 \mathrm{~g}^{-1}$, respectively.

It is relevant to remember that to study the concentration of a certain mineras in food, as a source of nutrition, it is necessary

Table 3. Mean values of mineral composition in mango solid mixtures for refreshments of four different brands.

\begin{tabular}{|c|c|c|c|c|}
\hline \multirow[b]{2}{*}{ Parameters } & \multicolumn{4}{|c|}{ Brands } \\
\hline & A & B & $\mathrm{C}$ & $\mathrm{D}$ \\
\hline Calcium (mg.100 g $\mathrm{g}^{-1}$ ) & $6306,92 \pm 211,02^{a}$ & $1613,47 \pm 159,31^{b c}$ & $1442,08 \pm 42,27^{c}$ & $3329,43 \pm 841,20^{b}$ \\
\hline Sodium (mg.100 g $\mathrm{g}^{-1}$ ) & $4557,95 \pm 0,96^{\mathrm{b}}$ & $2317,76 \pm 1017,10^{c}$ & $7118,22 \pm 2,51^{\mathrm{a}}$ & $5898,84 \pm 143,06^{\mathrm{ab}}$ \\
\hline Potassium (mg.100 $\left.\mathrm{g}^{-1}\right)$ & $1389,33 \pm 353,10^{\mathrm{a}}$ & $289,72 \pm 98,88^{b}$ & $839,79 \pm 0,30^{\mathrm{ab}}$ & $589,85 \pm 211,91^{\mathrm{ab}}$ \\
\hline Magnesium (mg.100 g ${ }^{-1}$ ) & $112,59 \pm 7,60^{\mathrm{b}}$ & $80,38 \pm 2,53^{\mathrm{b}}$ & $111,17 \pm 15,69^{b}$ & $573,41 \pm 2,07^{\mathrm{a}}$ \\
\hline Iron (mg.100 g $\left.\mathrm{g}^{-1}\right)$ & $11,74 \pm 1,85^{\mathrm{a}}$ & $76,95 \pm 90,38^{\mathrm{a}}$ & $18,27 \pm 0,65^{\mathrm{a}}$ & $199,15 \pm 24,48^{\mathrm{a}}$ \\
\hline Zinc (mg.100 $\mathrm{g}^{-1}$ ) & $10,41 \pm 0,70^{\mathrm{b}}$ & $9,42 \pm 3,97^{b}$ & $6,79 \pm 0,21^{b}$ & $33,04 \pm 8,47^{\mathrm{a}}$ \\
\hline Copper (mg.100 g $\left.\mathrm{g}^{-1}\right)$ & $3,18 \pm 0,31^{a}$ & $1,59 \pm 1,13^{\mathrm{a}}$ & $3,58 \pm 0,55^{\mathrm{a}}$ & $7,27 \pm 3,55^{\mathrm{a}}$ \\
\hline Manganese (mg.100 g $\left.{ }^{-1}\right)$ & $2,29 \pm 0,65^{\mathrm{a}}$ & $2,75 \pm 1,30^{\mathrm{a}}$ & $5,50 \pm 2,59^{a}$ & $4,18 \pm 3,76^{\mathrm{a}}$ \\
\hline
\end{tabular}

Mean values in the same line, with the same small letters, do not differ significantly at the level of $5 \%$ probability, according to Tukey's test. 
to consider the amount of nutrient present in the portion usually consumed, and also their bioavailability. Bioavailability of nutrients depends on the chemical form of the substance, on the contents of nutrient in the organism, and in the presence of complexants and other nutrients that can favorable or unfavorably interact with the nutrient under investigation, both in the intestinal tract and in the organic functions. Regarding mineral contents found in food, concentrations lower than $5 \%$ of IDR in an average food portion, even if the bioavailability is high, will not contribute significantly to raise the daily intake of the nutrient (FERREIRA, 2001; BRASIL, 2004).

In general, the high variations found between mineral contents in mango solid mixtures for refreshment may be explained by the lack of uniformity in the formulations used by the manufacturing industries.

\subsection{Contents of balance water and adsorption isotherms in solid preparations for mango powder refreshment}

The equilibrium moisture content and the adsorption isotherms of solid mixtures for refreshment of four different brands are shown in Table 4. It was observed, in general, that there was an increase in the contents of equilibrium water in all solid mixtures, in function of the increase of water activity. Such increase is more evident for water activities higher than 0.57 . It was also observed that brands A and D solid mixtures for refreshment are more hygroscopic than the other brands for all water activities.

Adsorption isotherms obtained for the solid mixtures of mango refreshment are shown in Figures 1 and 2. The adsorption isotherms were obtained by plotting the equilibrium moisture content of each solid mixture in function of water activity.

The time for the accomplishment of isotherms in the solid mixtures for mango refreshment was 20 days, for all brands. In the adsorption isotherms of the solid mixture for mango refreshment, it was verified that the samples presented physical changes in function of time: color change caused by water activity of 0.48 , when it was observed that, with the increase of the equilibrium moisture content, food dyes are probably activated, and the samples showed more intense colors. At 0.76

Table 4. Results of equilibrium water contents in four different brands of solid mixtures for mango refreshment.

\begin{tabular}{|c|c|c|c|c|c|}
\hline \multirow[t]{2}{*}{ Saturated solutions } & \multirow[t]{2}{*}{ Water activity } & \multicolumn{4}{|c|}{ Equilibrium moisture content (g.g $\mathrm{g}^{-1}$ dry matter) } \\
\hline & & $\mathrm{A}$ & $\mathrm{B}$ & $\mathrm{C}$ & $\mathrm{D}$ \\
\hline $\mathrm{K}_{2} \mathrm{CO}_{3}$ & 0.48 & 0.0054 & 0.0053 & 0.0042 & 0.0081 \\
\hline $\mathrm{Mg}\left(\mathrm{NO}_{3}\right)_{2}$ & 0.55 & 0.0102 & 0.0064 & 0.0059 & 0.0089 \\
\hline $\mathrm{NaBr}$ & 0.57 & 0.0166 & 0.0077 & 0.0106 & 0.0139 \\
\hline $\mathrm{NaCl}$ & 0.76 & 0.0885 & 0.0428 & 0.0509 & 0.0561 \\
\hline $\mathrm{SnCl}_{2}$ & 0.84 & 0.1055 & 0.0569 & 0.0674 & 0.0629 \\
\hline $\mathrm{BaCl}_{2}$ & 0.92 & 0.6387 & 0.6815 & 0.5761 & 0.6008 \\
\hline
\end{tabular}

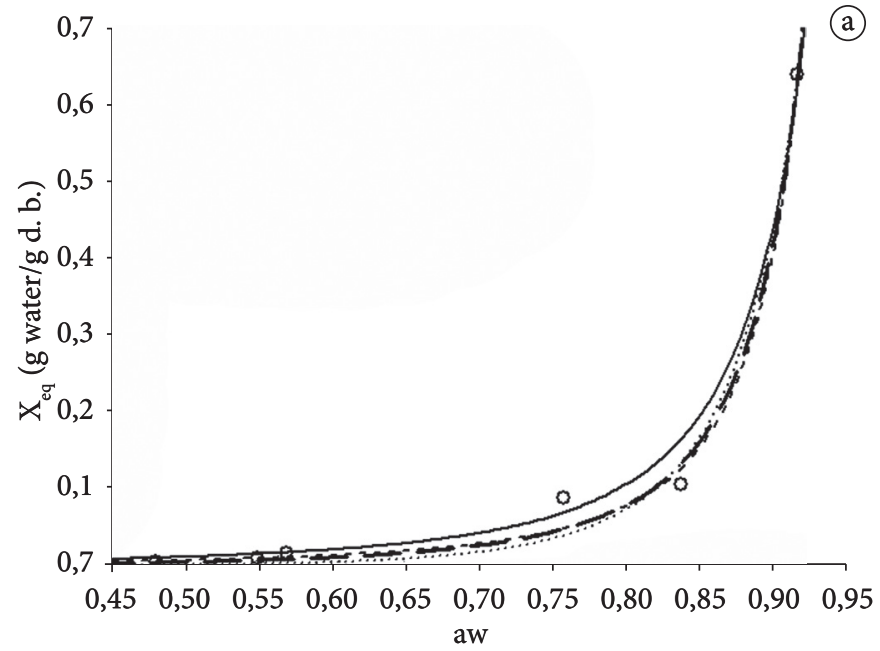

$$
\begin{array}{rl|}
\hline \circ & \text { Experimentais } \\
---- & \text { GAB } \\
- & \text { BET } \\
\cdots \cdots \cdots \cdots \cdots & \text { HENDERSON } \\
- & \text { OSWIN } \\
\hline
\end{array}
$$

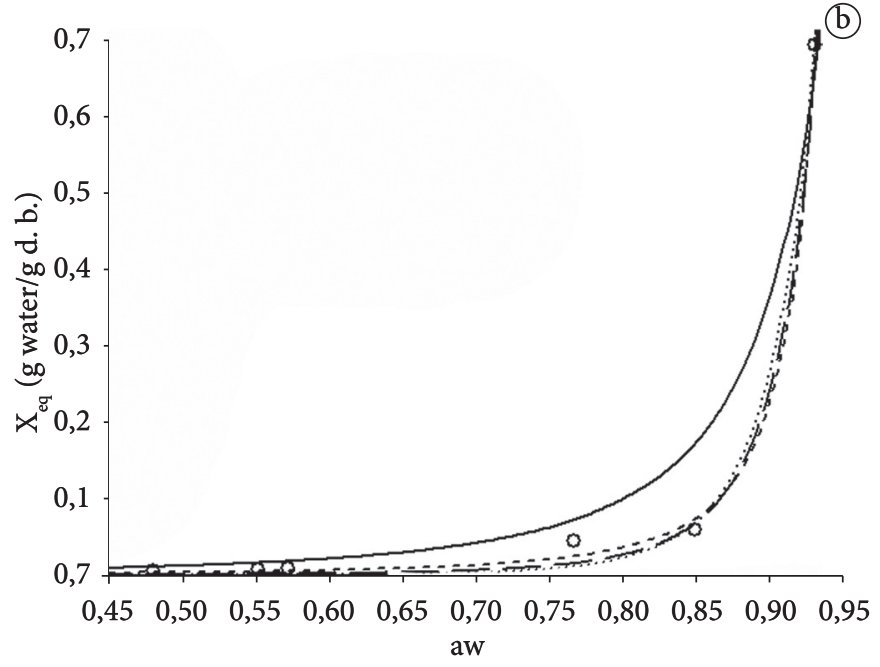

- Experimentais

- - - - GAB

BET

HENDERSON

OSWIN

Figure 1. Comparison of the values observed and predicted, for adsorption isotherm of solid mixture for mango refreshment: a) brand A; b) brands $\mathrm{B}$ at a temperature of $21^{\circ} \mathrm{C}$. 
water activity, the samples began to liquefy; and in 0.92 water activity the solid mixtures became completely liquid. Teixeira (1997) highlights that, the purest substances, such as sugars and salts, may undergo phase changes throughout the study of an isotherm, due to the equilibrium moisture content, because they are hygroscopic. Small changes in aroma of the solid preparations for refreshment were observed in the different brands. In the low and average water activity, from 0.45 to 0.65 , a soft and characteristic aroma was observed. In intermediate water activities, from 0.65 to 0.80 , the aroma was intense and characteristic, whereas in the high water activities, from 0.80 to 0.90 , a soft aroma was felt again, probably, due to the dilution of the sample in the atmosphere.

At the first part of the adsorption isotherms, where $a_{w}$ varies from 0.45 to 0.65 , a small increase of water contents was observed, with a strong increase of $\mathrm{a}_{\mathrm{w}}$. Although the chemical composition of the solid mixtures showed high contents of non-reductor sugars, ranging from 79.17 to $84.13 \%$ in the four brands investigated, in this range, the solid mixtures proved to be little hygroscopic. According to Telis and Sobral (2001), this behavior is typical of food rich in sugars; which was also verified in their study with Suriname cherry powder in low water activity. It is important to bear in mind that the adsorption of water in dehydrated food is caused, mainly, by the chemical nature of the organic components, such as sugars (mainly in fruits); by the existence of inter-molecular forces, type Van der Waals; by the ability of hydroxilic groups to connect with water molecules; and by the process used in the dehydration (PEREIRA, 2000).

All the water in this $a_{w}$ range is formed by successive monolayers of water molecules, kept by weaker and weaker hydrogen connections and also by connections, type Van Der Waals (LOISEL, 1988; COSTA, 1997). Although the

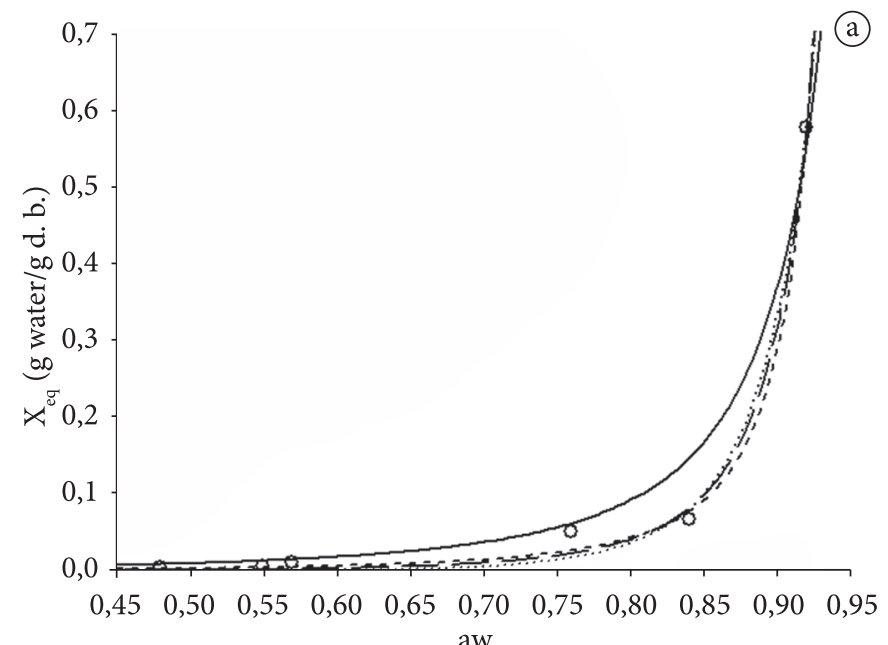

aw

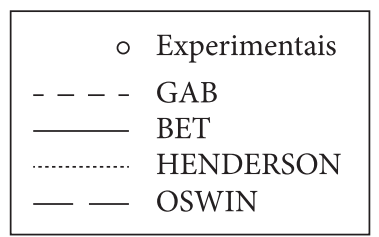

water molecules are still strongly oriented, as a function of their polar groups contained in the powdered food products, in this $\mathrm{a}_{\mathrm{w}}$ range, the energy needed for the connection of water molecules decreased and its mobility was weak. Therefore, its participation in chemical reactions was very limited (RIGANAKOS; DEMERTZIS; KOTOMINA, 1989, 1994).

In the second part of the adsorption isotherms, where $\mathrm{a}_{\mathrm{w}}$ varies from 0.65 to 0.80 , a relatively important increase in water contents was observed, as a function of the increase of $\mathrm{a}_{\mathrm{w}}$. Such evolution is characteristic of polar products of high connection energy, which are located inside the particles of the different solid mixtures investigated. However, such observation may only be confirmed with more replications than those carried out in this study.

In the last part of the adsorption isotherms, where $a_{w}$ varies from 0.85 to 0.90 , a high increase in the water contents was observed. Such increase is possibly due to the presence of soluble compounds and porosity in the solid mixtures of the four refreshment brands investigated. It is relevant to emphasize that the high hygroscopicity of these solid mixtures is also associated to their respective chemical and mineral composition with high contents of non-reductor sugars and sodium. According to Cheftel and Cheftel (1997) the water in this phase of isotherms is the one used as solvent of compounds, and it is linked by weak forces of capillary or osmotic origin. This fraction of water is also available for biochemical reactions.

\subsection{Mathematical models applied to the adsorption isotherms of solid mixtures for mango powder refreshment}

Table 5 shows both the parameters values for the mathematical models fitted to the experimental data and the values of the

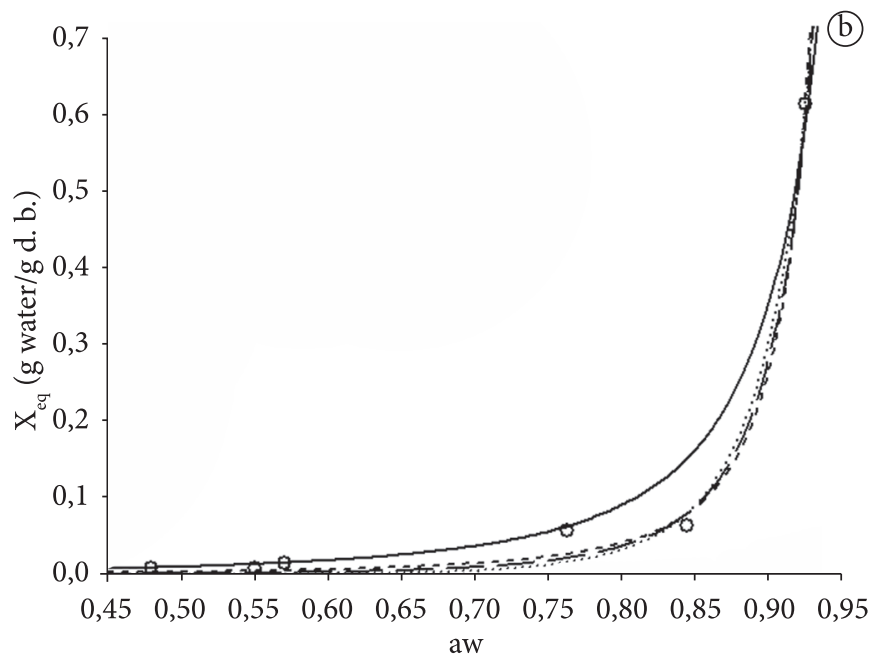

- Experimentais

$$
\begin{array}{ll}
---- & \text { GAB } \\
\hdashline-\ldots & \text { BET } \\
\cdots \cdots \cdots \cdots & \text { HENDERSON } \\
- & \text { OSWIN }
\end{array}
$$

Figure 2. Comparison between the values observed and predicted for the adsorption isotherm of solid mixture for mango refreshment: a) brand $\mathrm{C}$; b) brand $\mathrm{D}$ at a temperature of $21^{\circ} \mathrm{C}$. 
Table 5. Parameters of adsorption isotherms fitted to models of mango solid mixture, correlation coefficient $\left(\mathrm{R}^{2}\right)$ and mean error $(\mathrm{E})$, at $21^{\circ} \mathrm{C}$.

\begin{tabular}{|c|c|c|c|c|c|c|}
\hline \multirow[t]{2}{*}{ Models } & \multirow[t]{2}{*}{ Trade brands } & \multicolumn{3}{|c|}{ Parameters } & \multirow[t]{2}{*}{$\mathrm{R}^{2}$} & \multirow[t]{2}{*}{ E (\%) } \\
\hline & & $X_{m}$ & $C$ & $K$ & & \\
\hline \multirow[t]{5}{*}{ Gab } & $\mathrm{A}$ & 0.1876 & 0.0183 & 1.018 & 0.997 & 19.92 \\
\hline & B & 0.1966 & 0.0067 & 1.043 & 0.999 & 32.73 \\
\hline & $\mathrm{C}$ & 0.0985 & 0.0164 & 1.038 & 0.999 & 25.10 \\
\hline & $\mathrm{D}$ & 0.0950 & 0.0164 & 1.041 & 0.998 & 40.88 \\
\hline & & $X_{m}$ & C & $n$ & & \\
\hline \multirow{3}{*}{ Bet } & $\mathrm{C}$ & 0.1788 & 0.0286 & 499.8 & 0.986 & 42.9 \\
\hline & $\mathrm{D}$ & 0.2360 & 0.0212 & 500.4 & 0.986 & 35.48 \\
\hline & & $a$ & $b$ & & & \\
\hline \multirow[t]{2}{*}{ Henderson } & A & 0.2050 & 2.7712 & & 0.989 & 54.19 \\
\hline & B & 0.1378 & 2.6630 & & 0.997 & 64.17 \\
\hline \multirow[t]{4}{*}{ Oswin } & A & 0.0047 & 2.0080 & & 0.992 & 29.65 \\
\hline & $\mathrm{B}$ & 0.0005 & 2.9423 & & 0.997 & 57.63 \\
\hline & $\mathrm{C}$ & 0.0013 & 2.4933 & & 0.996 & 48.12 \\
\hline & $\mathrm{D}$ & 0.0011 & 2.5697 & & 0.994 & 56.52 \\
\hline
\end{tabular}

correlation coefficients and medium/average error. According to the values of $\mathrm{R}^{2}$, it is observed that all equations were well fitted to the adsorption isotherms of the different brands of solid mixture for refreshment; however, for the evaluation of the best fitting, it was taken into account the lowest value of the relative medium/average error (E). Therefore, it may be visualized, that GAB model was better fitted to brands D and B, C and B, with error of 25.10 and $32.73 \%$, respectively; whereas BET model, was better fitted for brands A and C. Moura et al. (2004) and Fadini et al. (2006) found values for the BET model between 2.61 and $28.10 \%$ and between 1.72 and $6.88 \mathrm{Gab}$ model for desorption isotherms of nuts. The high values of average error can be associated with small variations in the achievement of equilibrium moisture of the product. The Henderson model presented quite high errors for all brands of solid mixtures, and brand A presented the lowest error in relation to the others. Concerning the Oswin model, brand A was the best fitted. Fadini et al. (2006), working with isotherms of moisture sorption and studying the stability of macadamia nuts compressed into tablets at $25^{\circ} \mathrm{C}$, verified that the $\mathrm{GAB}$ model was the most appropriate, followed by the BET and Oswin models.

Regarding the moisture contents in molecular monolayer $\left(X_{m}\right)$ for the solid mixtures for refreshment found by the models applied, it was observed that the BET model presented the highest values varying from 0.1788 to 0.2379 in the four different brands. The $X_{m}$ values for GAB, Henderson and Oswin models were lower than those found for BET, and varied from 0.0950 to $0.1966 ; 0.1378$ to $0.2050 ; 0.0011$ to 0.0047 , respectively.

\section{Conclusions}

The physiochemical results have shown that solid mixtures for refreshments are considerable sources of ascorbic acid and reductor sugars and, in relation to mineral composition; they are important sources of calcium, sodium and potassium.

Regarding moisture contents in the molecular monolayer $\left(X_{m}\right)$ for the solid mixtures of refreshment found through the applied models, it was possible to observe that the BET model presented the highest values in the different brands investigated. The GAB model was the best fitted for brands D and B, with error of 19.92 and $40.88 \%$, respectively, whereas the BET model fitted best for brands A and D.

The Henderson, Oswin and BET models showed values higher than the average error by the GAB model for all solids mixtures of refreshment brands.

\section{Ackowledgements}

The authors are grateful to FUNCAP - Foundation of Support and Aid to Research - State of Ceara for the financial support to the present work.

\section{References}

ANSELMO, G. C. S. et al. Determinação da higroscopicidade do cajá em pó por meio da secagem por atomização. Revista de Biologia e Ciência da Terra, v. 6, n. 2, p. 58-65, 2006.

ASSOCIATION OF OFFICIAL AGRICULTURAL CHEMISTS - AOAC. Official Methods of Analysis Association of the Agriculture Chemistry, Analytical Chemistry. Washington: AOAC, 1995. v. 2, p. 16-18.

BASTOS, D. S. et al. Desidratação da polpa de manga "Tommy Atkins" a técnica de Foam mat drying - avaliações químicas, físico-químicas e sensoriais. Brazilian Journal of Food Technology, v. 8, n. 4, p. 283-290, 2005.

BRASIL. Ministério da Agricultura e do Abastecimento. Instrução normativa ${ }^{\circ} 012$, de 10 de setembro de 1999. Padrões de Identidade 
e Qualidade para Polpa de frutas. Diário Oficial da República Federativa do Brasil, Brasília, DF, 13 set. 1999.

BRASIL. Ministério da Saúde. Agência Nacional de Vigilância Sanitária. Consulta Pública n 80, de 13 de dezembro de 2004. Dispõe sobre o regulamento Técnico sobre a ingestão diária recomendada (IDR) de proteína, vitaminas e minerais. Diário Oficial da República Federativa do Brasil, Brasília, DF, 17 dez. 2004.

BRASIL. Ministério da Saúde. Agência Nacional de Vigilância Sanitária. Métodos físico-químicos para análise de alimentos. Brasília: Ministério da Saúde, 2005.

BRUNINI, M. A.; DURIGAN, J. F.; OLIVEIRA, A. L. Avaliação das alterações em polpa de manga Tommy-Atkins congeladas. Revista Brasileira de Fruticultura, v. 24, n. 3, p. 651-653, 2002. http:// dx.doi.org/10.1590/S0100-29452002000300019

BUENO, S, M. et al. Avaliação da qualidade de polpas de frutas congeladas. Revista do Instituto Adolfo Lutz, v. 62, n. 2, p. 121-126, 2002.

CALEGUER, V. F. Avaliação sensorial de preparados sólidos para refresco sabor laranja: análise descritiva, aceitabilidade e impactos da embalagem na intenção de compra. 2005. 159 f. Dissertação (Mestrado em Tecnologia de Alimentos)-Universidade Estadual de Londrina, Londrina, 2005.

CALEGUER, V. F.; BENASSI, M. T. Efeito da adição de polpa, carboximetilcelulose e goma arábica nas características sensoriais e aceitação de preparados em pó para refrescos sabor laranja. Ciência e Tecnologia de Alimentos, v. 27, n. 2, p. 270-277, 2007. http:// dx.doi.org/10.1590/S0101-20612007000200010

CARLOS, L. A.; RESENDE, J. V.; CAL-VIDAL, J. Redução da higroscopicidade de pós-liofilizados pela indução da cristalização em soluções-modelo de açúcares constituintes de frutas. Brazilian Journal of Food Technology, v. 8, n. 2, p. 163-173, 2005.

CHEFTEL, J. C.; CHEFTEL, H. Introduction a la biochimie et à la techonologie des aliments. Lavoisier: Tec. et Doc., 1997.

CORREAA, P. C. et al. Equilíbriohygroscopic de milheto, alpiste e painço: obtenção e modelagem. Revista Brasileira de Engenharia Agrícola e Ambiental, v. 10, n. 1, p. 162-167, 2006.

COSTA, J. M. C. Contribution a l'étude des propriétés rheologiques sés farines de blé: influence de la composition, de l'hydratation et de la distribuition granulometrique dês particules. 1997. $168 \mathrm{f}$. Thése (Docteur)-Ecole Nationale Superieur d'Agronomie et dês Industries Alimentaires, Nancy, 1997.

COSTA, M. C. Vida de prateleira de confeitos de abacaxi (Ananás comosus Morr L) semidesidratado. 1991. 157 f. Dissertação (Mestrado em Ciências dos Alimentos)-Universidade Federal de Lavras, Lavras, 1991.

FADINI, A. L. et al. Isotermas de sorção de umidade e estudo de estabilidade de macadâmias drageadas. Brazilian Journal Food Technology, v. 9, n. 2, p. 83-88, 2006.

FELIPE, E. M. F. et al. Avaliação da qualidade de parâmetros minerais de pós-alimentícios obtidos de casca de manga e maracujá. Alimentos e Nutrição, v. 17, n. 1, p. 79-83, 2006.

FERREIRA, C. D.; PENA, R. S. Comportamento higroscópico da farinha da farinha de pupunha (Bactris gasipaes). Ciência e Tecnologia de Alimentos, v. 23, n. 2, p. 251-255, 2003. http://dx.doi. org/10.1590/S0101-20612003000200025

FERREIRA, K. S. Concentrações de cálcio e de magnésio em alguns alimentos consumidos no Brasil. Brazilian Journal Food Technology. Preprint Série, v. 68, p. 123-130, 2001.

FUJII, F. O. Plus do sabor - A adição de polpa revigora a disputa dos fabricantes de refrescos em pó. Doce revista, v. 82, p. 32-50, 1999.
GENIN, N.; RENÉ, F. Analyse du role de la trasition vitreuse dans lês procedes de conservation agro-alimentaires. Journal of Food Engineering, v. 26, p. 391-408, 1995. http://dx.doi. org/10.1016/0260-8774(94)00059-I

GOMES, P. M. A.; FIGUEIRÊDO, R. M. F.; QUEIROZ, A. J. M. Armazenamento da polpa de acerola em pó a temperatura ambiente. Ciência e Tecnologia de Alimentos, v. 24, n. 3, p. 384-389, 2004. http://dx.doi.org/10.1590/S0101-20612004000300014

GREESPAN, L. Moisture fixed points of binary satured aqueuos solutions. Journal of Research of the National of Standards A: Physics and Chemistry, v. 81, n. 1, p. 89-96, 1977.

GRIZOTTO, R. K.; AGUINE, J. M.; MENEZES, H. C. Frutas estruturadas de umidade intermediária obtidas de polpas concentradas de abacaxi, manga e mamão. Ciência e Tecnologia de Alimentos, v. 25, n. 4, p. 691-697, 2005. http://dx.doi.org/10.1590/ S0101-20612005000400011

INSTITUTO NACIONAL DE METROLOGIA, NORMALIZAÇÃO E QUALIDADE INDUSTRIAL - INMETRO. Preparado sólido artificial para refresco (pó para refresco). São Paulo: INMETRO, 2007. Disponível em: <http://www.inmetro.gov.br/consumidor/ produtos/refresco.asp $>$. Acesso em: 14 maio 2008.

KUROZAWA, L.E.; EL-AOUAR, A. A.; MUR, F. E. X. Obtenção de isotermas de cogumelo in natura e desidratado osmoticamente. Ciência e Tecnologia de Alimentos, v. 25, n. 4, p. 828-834, 2005.

LOISEL, C. Contribution a l'étude dês propriétés rhéologiques de quelques poudres alimentaires: influence dês conditions hygrométriques. 1988. 250 f. Thése (Docteur)- Université de Nantes, Nantes, 1988.

LUZ, G. R. et al. Estudo das isotermas de equilíbrio do farelo de soja. Ciência e Tecnologia de Alimentos, v. 26, n. 2, p. 408-413, 2006. http://dx.doi.org/10.1590/S0101-20612006000200025

MARTINS, M. Açúcar invertido: propriedades e aplicações. Revista Food Ingredients: Guia 2001 de fornecedores, v. 2, n. 10, p. 1-97, 2001.

MORGANO, M. A.; QUEIROZ, S. C. N.; FERREIRA, M. M. C. Determinação dos teores de minerais em sucos de frutas por espectrometria de emissão óptica em plasma indutivamente acoplado. Ciência e Tecnologia de Alimentos, v. 19, n. 3, p. 344-348, 1999.

MOURA, R. S. F. et al. Modelagem matemática para isotermas em polpa de caju. Revista de Biologia e Ciências da Terra, Belo Horizonte, v. 4, n. 2, p. 32-40, 2004.

OLIVEIRA, F. M. N.; FIGUEIREDO, R. M. F.; QUEIROZ, A. J. M. Análise comparativa de polpas de pitanga integral, formulação e em pó. Revista Brasileira de Produtos Agroindustriais, v. 8, n. 1, p. 25-33, 2006.

PENA, R. S.; RIBEIRO, C. C.; GRANDI, J. G. Aplicação de modelos matemáticos bi e tri paramétricos na predição de isotermas de adsorção de umidade do guaraná (Paullinia cupana) em pó. Ciência e Tecnologia de Alimentos, v. 20, n. 1, p. 8-11, 2000. http://dx.doi. org/10.1590/S0101-20612000000100002

PEREIRA, A. Avaliação microestrutural de pós de suco de maracujá obtidos por spray drying. 2000. 66 f. Dissertação (Mestrado em Ciências dos Alimentos)-Universidade Federal de Lavras, Lavras, 2000.

PEREIRA, I. E.; QUEIROZ, A. J. M.; FIGUEIREDO, R. M. F. Características físico-químicas do tomate em pó durante o armazenamento. Revista de Biologia e Ciência da Terra, v. 6, n. 1, p. 83-90, 2006. 
RESENDE, O.; CORRÊA, P. C.; GONELI, A. L. D.; RIBEIRO, D. M. Isotermas e calor isostérico de sorção do feijão. Ciência e Tecnologia de Alimentos, v. 26, n. 3, p. 626-631, 2006.

RIGANAKOS, K. A.; DEMERTZIS, P. G.; KOTOMINAS, M. G. Water sorption by wheat and soy flour: comparison of the re methods. Journal Cereal Science, v. 20, p. 101-106, 1994. http://dx.doi. org/10.1006/jcrs.1994.1050

RIGANAKOS, K. A.; DEMERTZIS, P. G.; KOTOMINAS, M. G. Gas chromatographic study of water sorption by wheat flour. Journal Cereal Science, v. 9, p. 261-271, 1989. http://dx.doi.org/10.1016/ S0733-5210(89)80008-6

SILVA, P. T. et al. Sucos de laranja industrializados e preparados sólidos para refrescos: estabilidade química e físico-química. Ciência e Tecnologia de Alimentos, v. 25, n. 3, p. 1-10, 2005.
SLADE, L.; LEVINE, H. Water and the glass transition - Dependence of the glass transition on composition and chemical structure: special implications for flour functionality in cookie baking. Journal of Food Engineering, v. 24, p.431-509, 1995. http://dx.doi. org/10.1016/0260-8774(95)90766-5

TEIXEIRA, N. R. O. Isotermas de sorção de umidade: técnicas de obtenção e aplicações: In: JARDIM, D. C. P.; GERMER, S. P. M. Atividade de água em alimentos. Campinas: Instituto de Tecnologia de Alimentos, 1997. cap. 6, p. 1-11.

TELIS, V. R. N.; SOBRAL, P. J. A .Glass transitions and state diagram for freezer-dried pineapple. Lebensmittel Wissenchaft Journal of Food Technology, v. 34, n. 4, p. 199-205, 2001. http://dx.doi. org/10.1006/fstl.2000.0685 